KEY WORDS

Fiscal policy

Tax administration

Public finance

Law and regulations

International financial institutions

Case studies

Evaluation

Argentina

\section{Miguel Braun}

Policy Director, Centre for the Implementation of Public Policies Promoting Equity and Growth (CIPPEC),

Argentina

- mbraun@cippec.org

\section{Nicolás Gadano}

Associate Researcher, CIPPEC

Lecturer with the Public Policies

Master's Programme,

Universidad Di Tella,

Argentina

- ngadano@fibertel.com.ar

\section{What are fiscal rules for?}

\section{A critical analysis of the Argentine experience}

\author{
Miguel Braun and Nicolás Gadano
}

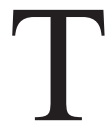

his article undertakes a critical examination of the usefulness

of fiscal responsibility laws in situations of institutional weakness. It analyses the case of Argentina, where prodigal use of fiscal rules (two different laws in just five years) contrasts with their limited effectiveness for fiscal policy sustainability and transparency, and it confirms that in situations of institutional weakness a fiscal responsibility law is unlikely to constrain government decision-making to the extent necessary to correct the behaviour of the public finances. The case of Argentina thus provides a warning for supporters of fiscal rules. When fiscal credibility is low and institutions weak, not only may such rules be fiscally ineffective, but non-enforcement may weaken yet further the fragile institutional context which made them so ineffective to begin with. 
I

\section{Introduction}

"This was the sweet song the Sirens sang, and my heart was filled with such a longing to listen that I ordered my men to set me free... But they swung forward over their oars and rowed ahead, while Perimedes and Eurylochus jumped up, tightened my ropes and added more."

Homer, The Odyssey, Book XII. ${ }^{1}$

Both theoretical studies and the recommendations of international organizations have borne witness to a growing faith in the ability of fiscal rules to contribute to fiscal solvency in developing countries. The theoretical argument evokes the scene of Ulysses and the Sirens quoted above, in which Ulysses asks his sailors to tie him to the mast to save him from succumbing to the lure of the Sirens' song. Rules are seen as legal and institutional constraints that can prevent opportunistic politicians from attempting to overspend. In particular, rules are expected to counteract the bias towards fiscal deficits created by the common ownership of public resources, principal-agent problems and the problems of time inconsistency identified in recent economic policy publications. ${ }^{2}$

This position is an application of the "rules rather than discretion" principle developed by Kydland and Prescott (1977) and is paralleled by the arguments in favour of central bank independence in the conduct of monetary policy. ${ }^{3}$ Kopits (2001), for example, argues that the main benefit of having a set of permanent, well-designed and properly implemented fiscal rules to prevent a bias towards deficit spending is that this establishes a depoliticized framework for fiscal policy, rather like the depoliticization of monetary policy under an inflation targeting regime.

Fiscal responsibility laws have been enacted in South American countries such as Brazil, Chile and

\footnotetext{
$\square$ The authors are grateful for the research assistance provided by Ariel Dvoskin and the comments of Juan Pablo Jiménez and Cynthia Moskovits.

1 Penguin Classics version (Homer, 2003).

2 See Drazen (2002) and Persson and Tabellini (2000), two recent works which provide a summary of this literature.

${ }^{3}$ See, for example, Cukierman (1992).
}

Argentina. In Brazil and Chile they have been fairly successful in maintaining fiscal solvency, so far at least, and proponents point to this as a vindication of their arguments. In Argentina, however, the results have been poor, if not non-existent, and the debate does not seem to have cast any light on the cause of this difference.

In our view, the argument in favour of fiscal responsibility laws expounded in the first two paragraphs of this introduction is insufficiently specified. It must be explicitly stated, we believe, that countries planning to introduce fiscal responsibility legislation need to have institutions strong enough to ensure (i) that the fiscal rules are precisely formulated, with no room for interpretations that distort their goals and (ii) that these rules are applied rigorously and in a way that is consistent with their provisions, so that neither the nation's executive branch nor lower levels of government can subvert it.

Kopits' argument, for example, touches on this issue, but does not clearly point out that the conditions he describes cannot simply be assumed to be in place: before venturing to pass a fiscal responsibility law, it is necessary to check that these conditions have been met and to undertake the necessary improvements and changes. In the following pages we shall show in detail that, at the time fiscal rules were beginning to be considered and applied in the region, Argentina was a prime example of an institutional context unsuited to their successful application.

Furthermore, as will be shown, the fiscal rules approved in Argentina have been more in the nature of a response to immediate political and economic problems than of mechanisms intended to make a permanent contribution to fiscal solvency. The flouting of these rules has not only revealed the inability of fiscal responsibility laws alone to improve fiscal performance 
independently of the institutional context, but has actually exacerbated institutional fragility and further discredited the legal system in the eyes of society.

Section II of this study summarizes the recent literature on the effectiveness of fiscal rules. Section
III looks at the experience of Argentina with the implementation of fiscal rules prior to the passing of the fiscal responsibility laws. Section IV then analyses their content and section V, lastly, presents some conclusions.

\section{II}

\section{What are fiscal rules, and what are they for?}

Before going further, we need an operational definition of fiscal rules. We shall follow Kopits and Symansky (1998), for whom a fiscal rule is a permanent (or lasting) constraint on fiscal policy expressed through fiscal results indicators such as the fiscal deficit, the debt level or some component of spending. When we speak of fiscal rules in this study, we are referring to numerical rules. This is an important point because many studies use a broader definition of fiscal rules, extending the concept to rules of procedure that govern the fiscal policy-making process and transparency rules that determine what fiscal information has to be made public. $^{4}$

The same authors argue that some of the key variables are: the specific numerical target laid down by the rule (it must be clear, measurable and as broad as possible); the period over which the rule is to be applied (the longer the better); the legal instruments used (of the highest status possible, ideally constitutional level); the level of government to which they apply (the wider the better); and the penalties for non-compliance (the harsher the better, ideally including criminal liability for officials). The rules usually include "escape clauses" as well, i.e., mechanisms that provide flexibility in special circumstances to forestall undesirable procyclical effects.

The justifications for the establishment of rules of this type are set out in the recent economic policy literature. This literature attributes differences in fiscal behaviour between countries in a similar economic situation to differences in political institutions and practices. According to Tommasi (1998), the economics problems that influence fiscal results can be divided

\footnotetext{
${ }^{4}$ See, for example, Alesina and Perotti (1996). These "rules of procedure" are akin to the standards traditionally applied to publicsector financial administration.
}

into two main categories: principal-agent problems and cooperation problems.

In the first category are problems deriving from the delegative character of the system of government. Voters elect their representatives and delegate to them the power to take decisions in the public interest. Since information is asymmetrical and the interests of representatives do not always coincide with those of the represented, the policies made may not always be the most desirable. One example in the fiscal area is the tendency for governments to increase spending in election years. ${ }^{5}$

Cooperation problems, meanwhile, are those arising from the interaction of different national and subnational groups in competition for public resources, which generates a tendency towards overspending and overborrowing. A classic example provided by Weingast, Shepsle and Johnsen (1981) shows that public spending may increase because of the common pool problem involved in the political interaction of regions with parliamentary representation. According to these authors, legislators have incentives to propose spending increases that would benefit their region because the resources are raised from taxes levied nationwide. Velasco (1999) analyses the common pool problem in a dynamic context and shows how it can lead to higher deficits and borrowing.

Tabellini and Alesina (1988) explain the fiscal deficit by time inconsistency (i.e., a lack of coherence in decision-making over time), associated with possible discrepancies between the preferences of present and future voters and the inability of the former to constrain the decisions of the latter. In these circumstances, the voters of the present tend to push up spending and

\footnotetext{
${ }^{5}$ See Drazen and Brender (2005) for a recent study of this issue.
} 
deficits to levels higher than the optimum for society as a whole.

The studies mentioned at the beginning of this section attribute different fiscal results in countries with similar economic institutions and conditions to differences in political institutions and practices. In particular, the cooperation, time inconsistency and principal-agent problems that influence fiscal results can vary in different countries and different time periods because of changes in political institutions that affect the incentives of those who wield the most influence over fiscal results. For example, Alesina and Perotti (1996) argue that when a country's budgetary process is more hierarchical (the executive has greater weight than the legislature, and the finance ministry than other ministries), fiscal solvency is greater. This is because the president and the finance minister are more conscious of the intertemporal budgetary constraints on the government than are congress and sectoral ministries, and are thus more careful of the fiscal results.

These are the arguments that underlie the defence of fiscal rules as a mechanism for improving fiscal solvency. When political actors have incentives to overspend, or a dynamic of non-cooperation leads to excessive expenditure, better results should be obtained when there is a numerical rule that places a ceiling on spending, the deficit or borrowing than when there is no such rule. Of course, the basic assumption underlying this analysis is that the rule is followed. ${ }^{6}$

However, it is not easy to find convincing empirical evidence of the effect of rules on fiscal results. Braun

\footnotetext{
${ }^{6}$ There are some critical voices in the literature. Milesi-Ferretti (2000), for example, argues that numerical rules can lead governments to engage in what is known as "creative accounting", i.e., alter the way the public accounts are measured to get a numerical result that meets the rule, when the target set by the rule is too demanding for the fiscal situation and the level of budgetary transparency is low.
}

and Tommasi (2004) argue that changes in fiscal rules at the national level are not common and that when they do occur, they are usually accompanied by other reforms that affect the fiscal results, thus making it harder to assign responsibility for fiscal changes to the alterations in the rules. This problem limits the explanatory potential of time series regressions within a country, and of regressions using data from a number of countries, owing to an insufficiency of observations; furthermore, a correlation between changes in rules and changes in results would be biased if it failed to take account of other reforms.

Given the heterogeneity of the results observed following the application of fiscal rules, some authors have suggested that, to be successful, such rules need to have strong political backing. ${ }^{7}$ If such were the case, however, we would have to ask whether it was not this very political support for fiscal discipline that was responsible for the improved performance of the public finances, irrespective of any formal rules. ${ }^{8}$ According to this line of reasoning, fiscal responsibility laws are simply a vehicle for building social consensus around the importance of fiscal discipline. Without that consensus, the rules alone would not guarantee any improvement in the behaviour of the public finances.

Given what has happened in Argentina, the lack of powerful empirical evidence to demonstrate the usefulness of rules in improving fiscal results does not surprise us. ${ }^{9}$ The next section describes the Argentine experience with fiscal rules, focusing particularly on the 2004 fiscal responsibility law, passed in the first half of that year.

\footnotetext{
${ }^{7}$ See Schick (2002) and Ter-Minassian (2006).

${ }^{8}$ If the formal establishment of rules reflected a voter preference for fiscal prudence, then the correlation between rules and fiscal prudence would suffer from omitted variable bias. The recent academic literature has tried to resolve these problems of identification, so far without much success.

${ }^{9}$ See Gadano (2003) for an analysis of the 1999 fiscal responsibility law.
} 
III

\section{Fiscal rules in Argentina}

Hegel remarks somewhere that all facts and personages of great importance in world history occur, as it were, twice. He forgot to add: the first time as tragedy, the second as farce.

Karl Marx, The Eighteenth Brumaire of Louis Bonaparte. ${ }^{10}$

Argentina overhauled its public-sector financial administration system in the $1990 \mathrm{~s}$, the main element in the transformation being the enactment of a new public-sector financial administration law (law 24.156 of September 1992) which redefined roles and procedures in the nation's public finances and the operation of supervisory agencies. Structured on the principle of normative centralization and operational decentralization, the reform assigned the leading role to the Ministry of Finance while delegating day-to-day budgetary management to the different local authorities and agencies. The Comptroller General (SIGEN) was given responsibility for internal auditing within the executive, while external auditing was assigned to the Office of the Auditor-General, which reports to the national Congress. ${ }^{11}$

According to studies of fiscal rules, the reform process spearheaded by law 24.156 did not introduce quantitative fiscal rules into the administration of the public finances but centred on so-called "rules of procedure", i.e., on provisions regulating budgetary processes and the administration of public funds.

The introduction of numerical fiscal rules began to be discussed in the second half of the 1990s as a result of two convergent phenomena. First, a burgeoning literature on fiscal rules helped to create an attitude favourable to their use. This favourable consensus extended to the multilateral lending organizations and was reflected in the lists of structural reform suggestions proffered by the International Monetary Fund (IMF) and World Bank to countries with assistance and financing programmes.

At the same time, the deterioration in international financial conditions towards the end of the decade put greater pressure on the performance of emerging

\footnotetext{
${ }^{10}$ International Publishers version (Marx, 1963).

${ }^{11}$ See Makón (1997).
}

economies and increased concern about trends in the public finances, particularly borrowing.

In Argentina, Congress had passed legislation to supplement the 1992 financial administration law. Law 24.629, enacted in February 1996, established restrictions on spending increases without earmarked financing, stricter transparency requirements for the budgetary accounts and an obligation for the executive to present Congress with a budget implementation statement once a quarter and with a progress report on the following year's budget each 30 June. The law included a new feature familiar from the debate on fiscal rules: penalties for non-compliance. Under the new law, officials responsible for breaches of the rules would be held personally liable towards third parties.

\section{The "fiscal convertibility" law}

In 1998, Congress began to debate what would later become the first fiscal responsibility law in Argentina, law 25.152. Originally labelled the public resources administration law, it became known to the public as the fiscal convertibility law. ${ }^{12}$

Discussion of the bill in Congress lasted just over a year, during which time macroeconomic conditions in Argentina altered sharply, significantly influencing its contents. In March 1998, when the original bill was submitted, the storm clouds of the international crisis that was to affect emerging economies were already appearing, but the Argentine economy had just grown by $8.1 \%$ in 1997 and $6.5 \%$ in the first half of 1998 . A year later, following the impact of the Russian crisis and the Brazilian devaluation, Argentina was in

\footnotetext{
${ }^{12}$ The then popularity of the "super rule" of the convertibility regime led to an attempt by the creators of the new fiscal legislation to create a forcible association between their bill and the currency/monetary mechanism that had put an end to inflation in 1991.
} 
recession, deflationary pressures were becoming more and more evident, and concern about the sustainability of the public accounts was spreading within and beyond the country. The strength of the convertibility system was called into question and the fiscal situation was seen as one of its weakest links. With an economy that had stopped growing and financing difficult to obtain, the government had to provide an assurance that it would adjust the accounts in future to whatever extent necessary, and passing law 25.152 was a good way of doing this. ${ }^{13}$

The numerical rules were the best-known aspect of this law. For the financial result, the rule in the original bill (a ceiling of $1 \%$ for the financial deficit) was replaced by a gradual deficit reduction timetable starting in 1999 and culminating with fiscal balance in 2003. ${ }^{14}$ Public spending growth was made conditional on gross domestic product (GDP) growth, the rule being that current primary spending could not be raised if economic activity declined. A Fiscal Countercyclical Fund (FAF) was also established, to be financed out of extraordinary concession and privatization receipts and a set percentage of tax revenues. ${ }^{15}$ The original bill also included a special article setting out the penalties for anyone breaching its provisions. However, they were the same as the existing penalties for the offence of dereliction of duty by a public official, so the article was deemed redundant and removed from the final draft. The law also included some considerations concerning fiscal transparency and reform of the State.

As was pointed out in the previous section, fiscal rules usually include escape clauses to forestall (or at least cushion) the procyclical effect that a rigid rule might have on fiscal policy, especially during a recession. The original bill for law 25.152 contained

\footnotetext{
${ }^{13}$ With a change of president in prospect for late 1999, the promised fiscal adjustment would have to be dealt with by the next government, a detail of no small importance for the timing of the vote.

${ }^{14}$ After setting a ceiling of $1.9 \%$ of GDP for 1999, the law established a procedure for recalculating that year's deficit that excluded exceptional receipts. On the basis of the recalculated deficit, a reduction of $0.4 \%$ was mandated for $2000,0.5 \%$ for 2001 and $0.6 \%$ for 2002, with balance to be achieved in 2003 .

${ }^{15}$ The FAF could accumulate resources up to a maximum of $3 \%$ of GDP, to be used during the recessionary phase of the economic cycle. De la Sota's original proposal included an initial contribution to the faf using the government's shares in privatized enterprises. Given that the bulk of these shares would be sold in the early months of 1999, principally those held in Yacimientos Petrolíferos Fiscales (YPF), reference to these resources was dropped in the final version of the Countercyclical Fund.
}

an escape clause that allowed numerical limits to be breached "....in cases of severe international crisis, catastrophe or internal emergency as determined by the executive branch". This contingency clause disappeared from the final version of the law, however. In mid1999, the characteristics of the convertibility regime and the difficulty of raising public financing made it unthinkable for Argentina to increase its fiscal deficit as a countercyclical response to the recession affecting its economy. On the contrary, all the signs served to reinforce the authorities' commitment to an immediate adjustment of the public accounts, even in an adverse macroeconomic context. Without a contingency clause, the rule required not only that the fiscal deficit be eliminated even in periods of recession and deflation, but that a Fiscal Countercyclical Fund be set up with part of the fiscal revenues.

The results of law 25.152 were disappointing. Its implementation in the early 2000 s coincided with the doomed efforts to prevent the collapse of the convertibility regime, which was ultimately abandoned in late 2001 in the midst of a deep political, economic and social crisis.

The deficit limits laid down in the law were modified in its first year of implementation and then disregarded. The ceiling on expenditure growth was respected in the years of recession (when there were no resources to increase spending with), but not in those of recovery. ${ }^{16}$ The Fiscal Countercyclical Fund was set up, but it never had the resources to operate in the way it was designed to. Although law 25.152 was never formally repealed, its resounding initial failure consigned it to oblivion.

\section{The "zero deficit" law}

In the second half of 2001, a few months before the political and economic crisis which led to the traumatic abandonment of the convertibility regime, the authorities tried to implement an extreme fiscal rule, far more ambitious in scope than the unenforced law 25.152. The new rule, known publicly as the "zero deficit law" and formally enacted by a reform to financial administration law 24.156, was meant to apply a very simple principle: no more should be spent

\footnotetext{
${ }^{16}$ Total public spending by the national public sector rose from $15.8 \%$ of GDP in 2002 to $18.4 \%$ in 2006 , and the 2007 budget projection is for $19.19 \%$ of GDP. Primary spending rose from $13.6 \%$ in 2002 to $16.3 \%$ in 2006 .
} 
each month than could be financed out of current State revenues. ${ }^{17}$

Although simple in its conception, the law proved to be wholly impracticable. The executive subjected pensions to cuts hitherto applied only to public-sector salaries, but did not achieve the much-vaunted "zero deficit". Although the law provided for the adjustment coefficient to be increased until the accounts were balanced, the scheme's political and social unviability meant that the salary and pension reduction had to be held at the original level. Some time later, when the convertibility system had collapsed, the zero deficit law would be ruled unconstitutional by the Supreme Court of Justice. ${ }^{18}$

The short, laboured existence of the extreme "zero deficit" law dramatically demonstrated how impracticable it was to place the whole weight of adjustment in the public accounts upon a mere written rule. Like law 25.152, the zero deficit law came to swell the growing list of unenforced laws in Argentina. ${ }^{19}$

\section{IV}

\section{A new fiscal responsibility law}

Public interest in the fate of fiscal rules was practically nil after the crisis of late 2001. The scale of the problems that had to be resolved (suspension of payments on the public debt, rescheduling of bank deposits, the breaking of public service contracts, high unemployment) meant that the flouting of the rules approved by law in 1999 became a non-priority issue to which few paid attention. The disappointing performance of law 25.152 was not discussed and still less was any reform mooted, either in Congress or in the executive. The law remained in force but its prescriptions were not complied with or

\footnotetext{
${ }^{17}$ The following text was incorporated into article 34 of financial administration law 24.156: "When estimated budgetary resources are insufficient to meet all planned budgetary credits, there will be a proportionate reduction in credits for the whole of the national public sector in order to maintain the balance between operating expenditure and budgetary resources. The reduction will affect credits intended for the payment of periodic remunerations of any type, including salaries, extra pay, family allowances and pensions, and transfers used by the receiving organizations or agencies to make these payments. The reduction in budgetary credits... will automatically entail the reduction of the remuneration affected, regardless of type, including salaries, extra pay, family allowances and pensions. The reductions in remuneration will be applied proportionately throughout the salary or pay scale, as appropriate, without discrimination of any kind. This law amends as necessary any legal, regulatory or contractual provision to the contrary, and the existence of irrevocably acquired rights may not be cited as grounds for opposing its operation".
}

were suspended by articles included in the budget laws for each financial year. ${ }^{20}$

In 2004, however, Congress approved a new fiscal responsibility law (FRL) numbered 25.917. The bill was sent to Congress by the executive on 15 June 2004, entering the House of Senators. Less than two months later, it had been passed by both houses of Congress and was enacted by the executive. Argentina had a new fiscal responsibility law.

The provisions of this law were designed to meet a number of objectives. In the interests of fiscal transparency, it established an obligation to prepare and publish standardized multiyear budgetary information for the national government and the provinces. Each year, the national government was obliged to present a macrofiscal framework that would be used as an input for preparing the budget in all administrative districts.

\footnotetext{
${ }^{18}$ In the judgement "Tobar versus the National State", the Supreme Court confirmed the unconstitutionality of law 25.453, arguing that it was "...contrary to the national Constitution to have a legal regime that leaves the determination of pay rates and food allowances to the discretion of the executive branch, not as an exceptional case that can be subjected to jurisdictional control, but as an economic policy tool intended to reduce public spending and stabilize the fiscal accounts as passing circumstances may require".

${ }^{19}$ The amendment establishing the zero deficit rule was removed from law 24.156 by an article in the 2003 budget act.

${ }^{20}$ The Ministry of Finance included articles suspending payments into the Fiscal Countercyclical Fund in the 2003, 2004, 2005 and 2006 budget laws. See articles 27 of law $25.565,40$ of $25.827,30$ of law 25.967 and 24 of law 26.078 .
} 
Regarding numerical rules, law 25.917 set the GDP growth rate as the ceiling for primary expenditure growth and prescribed budgetary balance after deduction of certain types of expenditure..$^{21}$ For the provinces, it established a borrowing constraint whereby debt servicing costs might not exceed $15 \%$ of the current revenues of the local administration concerned, after deduction of revenue-sharing (coparticipación) transfers to municipalities. All administrations were enjoined to create fiscal countercyclical funds.

The national government was empowered to agree financing programmes with any provinces that might require this, always provided the stipulations of the FRL were complied with. The Federal Fiscal Responsibility Council was created to oversee the application of the law; its members were representatives of the national and provincial governments and it was empowered to impose penalties for non-compliance that ranged from public disclosure of any breaches to the partial withholding of budgetary transfers from the centre (other than revenue-sharing resources).

A number of provisions in the FRL recapitulated limitations already established by law 25.152 , which was not repealed, and by financial administration law 24.156. Although law 25.152 did not have the adjustment clause of the FRL, article 2, subsection C limited primary public spending growth as a proportion of GDP. The prohibition on repaying debts associated with expenditure not earmarked in the budget, as established in article 24 of the FRL, appears in article 3, subsection A of law 25.152. The limitations on the ability of the executive to increase current spending to the detriment of capital spending and financial applications during the execution of the budget, as stipulated in article 15 of the FRL, reiterate the provisions of article 37 of law 24.156. It also repeated the ban on creating funds or agencies off budget or outside the general financial administration rules. The mandate of article 20 of the FRL to create a fiscal countercyclical fund is surprising given that a national fund with these characteristics, created by law 25.152, had been operating for a number of years.

Besides reflecting a certain lack of legislative technique, the redundant character of several of the provisions in the new FRL confirms something else:

\footnotetext{
${ }^{21}$ The rule relates to "adjusted" primary expenditure excluding costs tied to financing by international organizations and capital spending on basic social infrastructure. The same adjustment is to be applied when calculating the financial balance.
}

that the new law owed little to critical reflection on the performance of the fiscal rules operating up until that time. Given such a recent and traumatic precedent with fiscal rules, the debate about a new fiscal responsibility norm might have been expected to concentrate on the lessons of this earlier experience, seeking at least to ascertain why the law had been so poorly enforced. Approached in this way, the legislative changes would probably have been implemented by reforming existing laws and not by creating a new one. However, the experience with law 25.152 was not considered when the FRL was being prepared and debated in parliament, and its text makes no mention at all of the earlier legislation. It was other factors, arising from the economic and political circumstances of 2004, that determined the genesis and content of the FRL.

\section{The International Monetary Fund, the provinces and the new fiscal responsibility law}

Two convergent phenomena associated with the situation of post-crisis Argentina are to the fore in explaining the process that led to the approval of the new FRL: the vicissitudes of Argentina's testing relationship with the International Monetary Fund (IMF), and the conditional financial assistance provided by the central government to the provinces, which strongly influenced the substance of the law.

The dynamic of the relationship between Argentina and the IMF played a decisive role in the decision to enact a new fiscal rule. The IMF financing programme for Argentina negotiated in 2001 by Domingo Cavallo, a former minister, ended abruptly with the crisis that broke out at the end of that year. Following a "short" agreement signed by the provisional president, Eduardo Duhalde, in January 2003, in September of the same year the government of Néstor Kirchner signed a threeyear stand-by agreement providing for disbursements to cover Argentina's debt repayments to the Fund itself.

In the IMF view, fiscal reform (primarily involving a new system of federal revenue-sharing) had to be one of the main planks of the programme agreed upon. ${ }^{22}$ As part of the structural reforms to be implemented, the Argentine government undertook to send two bills to Congress: a revised tax revenue-sharing law and new fiscal responsibility legislation. The accord set

\footnotetext{
${ }^{22}$ See the statements by Anne Krueger in IMF (2003a).
} 
out a precise timetable for the initiatives: agreement on the principles of the legislation to be passed had to be reached with a "critical mass" of governors by March 2004. ${ }^{23}$

Consistently with the conceptual analysis carried out in section III, the IMF gave primary importance to the approval of new fiscal legislation that included rules. In the first programme review in late January 2004, the Fund authorities applauded the good performance of the Argentine fiscal accounts in the short term, but highlighted the need to assure the sustainability of fiscal improvements by implementing the promised legislative reform. ${ }^{24}$

In the second review, conducted in March 2004, the Fund emphasized the importance it attached to the fiscal reform commitments made:

\section{"In addition, progress is expected towards securing a political consensus for the new fiscal responsibility and coparticipation legislation. These are critical initiatives and the authorities need to ensure that the reforms that will be proposed to Congress provide a durable solution for the weaknesses of the current system-namely insufficient control over provincial finances, lack of incentives to raise own revenues at both levels of government, and a lack of equity in the distribution of resources among the provinces" (IMF, 2004a, pp. 12 and 13).}

The Fund continued to wait for the two bills (the reform of the revenue-sharing law and the new fiscal responsibility legislation) to be submitted to Congress. The revised structural targets of the programme included an ambitious timetable: submission of both bills to Congress by the end of May and their approval by the national and provincial legislatures by the end of August.

But the federal revenue-sharing reform, the "mother of all battles" in the fiscal discussion between the national government and the provinces, never reached Congress. Sensibly, the national government decided not to go ahead with a bill that would necessarily mean far-reaching negotiations with the provinces under political circumstances that provided no assurance of a reasonable outcome. In this context, the new

\footnotetext{
${ }^{23}$ See IMF (2003b).

${ }^{24}$ IMF (2004b).
}

fiscal responsibility bill became a sort of second-best option for the Fund because it could present approval of the FRL as a step forward with institutional reform in the fiscal area, and for the government because it prevented the stand-by programme from lapsing. Thus, the executive presented the bill for the FRL to Congress on 14 June 2004, the same day as the IMF mission began the third review of the agreement signed in September the previous year. ${ }^{25}$

The complex fiscal and financial relationship between the centre and the provinces, dominated by the delayed reform to the federal revenue-sharing regime, was significantly affected by the crisis of 2001. A number of subnational administrations had increased their expenditure and borrowings too far during the boom period and were having the utmost difficulty in adapting to a less favourable environment. In some cases, the financial commitments entered into tied up too large a portion of provinces' revenues. As revenues and financing dried up, many administrations had resorted to issuing quasi-currencies as the only way of meeting basic administration costs, principally the salaries of public-sector employees.

By February 2002, the new national government had reached a fiscal agreement with the provinces that was designed to resolve the most critical aspects of the situation. ${ }^{26}$ The debts of the provinces were taken over by the national government and renegotiated over long terms and at lower interest rates, and the revenuesharing ratios provided for in the legislation once again began to be applied. In return for financial assistance from the federal government, the administrations in the greatest fiscal and financial difficulties undertook, under bilateral agreements with the centre known as ordered financing programmes (PFOs), to reduce their imbalances and not to increase their borrowings. ${ }^{27}$ These programmes included financing from central government to meet deficits and debt repayments in exchange for a commitment to meet fiscal targets for reducing budget imbalances by rationalizing spending

\footnotetext{
${ }^{25}$ The third review was never completed and the stand-by programme was suspended. The Fund was dissatisfied with a number of "weaknesses" in the new fiscal responsibility legislation (IMF, 2005). ${ }^{26}$ Acuerdo Nación-Provincias sobre Relación Financiera y Bases de un Régimen de Coparticipación Federal de Impuestos, signed on 27 February 2002 and ratified by national law no. 25.570.

${ }^{27}$ The Programme for Ordered Financing of the Provincial Finances, aimed at the provincial states and the autonomous city of Buenos Aires, was formally created by national executive decree no. 2.263 dated 8 November 2002 .
} 
and increasing revenues, refraining from any debt or quasi-currency increases, and carrying out fiscal transparency and financial administration reforms. To ensure that the loans received were reimbursed, the provinces agreed to transfer their rights over federal revenue-sharing resources to the national government. The agreements included penalties for non-compliance by the provinces. ${ }^{28}$

The ordered financing programmes strongly influenced the contents of the 2004 FRL, which became a means to give greater institutional backing to the bilateral financing agreements between the national government and the provinces..$^{29}$ On the basis of article 26 of that law, the national government carried on signing agreements with some provinces and even using the same financial vehicle, the Trust Fund for Provincial Development (FFDP). ${ }^{30}$ The FRL shares with the ordered financing programmes the goal of capping the provinces' public debt, and the two instruments contain similar penalties for non-compliance. Most of the fiscal management and transparency requirements laid down in the PFOs subsequently reappeared in the text of the FRL. The coordination and oversight role exercised in the PFOs by the deputy minister for provincial relations was transferred to the Fiscal Responsibility Council created by the new legislation.

The relationship between the national government and the provinces was an issue that permeated the contents of the FRL but does not seem to have been critical in the timing of its approval. It may be speculated that, without the pressure from the Fund to pass the FRL, financial assistance to the provinces would have continued to be administered through PFOs.

\footnotetext{
${ }^{28}$ The national government signed PFOs with 17 provinces in 2002 , providing financing of 2.73 billion pesos to cover cash needs and public debt repayments. On a similar basis, PFOs were once again signed in 2003 (with financing of over 3 billion pesos from the national government) and 2004 (Cetrángolo and Jiménez, 2004).

${ }^{29}$ The Minister of Economy, Roberto Lavagna, publicly confirmed the connection between the new law and the ordered financing programmes (PFOs): "We see a case for bringing together a large part of the experience of these last three years in a law of a more permanent character. The idea behind this law is that all of us, in the national government and in the provinces, should work with common macroeconomic rules and projections, and with standards of transparency and coordination" (Lavagna, 2004).

${ }^{30}$ The FFDP, created by decree in 1995 to support reforms in the provincial states, began to be used as a provincial financing instrument by the national government in 2000 and 2001. The FFDP was also the means used to transfer the resources promised by the PFOs in 2002, 2003 and 2004, the funds being provided by the Treasury. In the last few years, the FFDP has been the instrument used to give the provinces the assistance provided for in the FRL.
}

\section{The operation of the 2004 fiscal responsibility law (FRL)}

At this early stage, the record of the new law has been mixed. As public revenues have grown along with economic activity, Argentina has significantly improved its fiscal accounts in recent years. However, during the 2005 fiscal year, the first to be affected by the FRL, the most important numerical rule of the new law was not met: adjusted primary spending grew by more than GDP. ${ }^{31}$

In the provinces, the Federal Fiscal Responsibility Council found that the spending and balance rules were met in 2005, although some administrations exceeded the borrowing limits. ${ }^{32}$ Looking ahead, the executive is seeking to change the method used to measure the limits on spending increases in the provinces to exclude specifically allocated expenditure financed from nonautomatic federal government contributions, with effect from 2007. If this amendment goes through, the FRL will be completely debased. ${ }^{33}$

The limits on the amendments the executive can make to the budget while it is being implemented, as laid down in article 15 of the FRL, were suspended temporarily by an article in the 2005 budget act voted through just a few months after this law had been passed, and permanently by means of a controversial reform to the financial administration law passed in mid-2006. ${ }^{34}$

There has been no progress, at least at the national level, in the aim of consolidating into the budget all the agencies and/or funds that are currently off budget. ${ }^{35}$

There has likewise been no progress with the publication of fiscal information as required by article 7 of the law. In the case of the national public sector, information on budget implementation, the public debt

\footnotetext{
31 See ASAP (2005).

${ }^{32}$ See Consejo Federal de Responsabilidad Fiscal (2006).

33 The change was included in article 20 of the 2007 budget bill presented to Congress. The system introduces perverse incentives: the provinces would be limited in their scope to increase spending out of their own resources (or their share of tax revenue-sharing income), but could do so using financing from discretionary central government transfers.

${ }^{34}$ This is law 26.124 of August 2006, which amended article 37 of law 24.156, increasing the powers of the executive to amend the budget voted through by Congress during its implementation.

${ }^{35}$ Article 3 of the FRL set a deadline of two years for these funds and agencies to be brought into the general budget. They have not been reincorporated in the 2007 budget bill, but an article has been added to this calling for "a timetable of activities for the completion of this inclusion process".
} 
and unfunded Treasury debt is being delayed by more than the three months allowed by the FRL. Occupational and employment information is not available. The Federal Fiscal Responsibility Council has started to publish information from the provinces, but this is incomplete and there are long delays.

Contrary to the terms of article 13 of the law, new funds have been created with associated spending that is not consolidated in the general budget. Article 17 , which creates an obligation to offset any revenuereducing tax measure by increasing resources elsewhere or reducing spending, has not been complied with. ${ }^{36}$

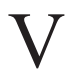

\section{Conclusions}

In Argentina, prodigality in the use of fiscal rules (two different laws in just five years) contrasts with the meagre results achieved. The rules have been all but ineffective in assuring the sustainability of fiscal policy, improving transparency and rooting out the collection of bad practices that have dominated the Argentine budgetary process for years.

The rapid and general neglect of the rules contained in the first fiscal responsibility law approved in Argentina (law 25.152 of 1999, known as the fiscal convertibility law) was largely associated with the macroeconomic crisis that broke out in late 2001. Five years later, however, in highly favourable economic circumstances, compliance with the provisions of the 2004 fiscal responsibility law, many of them carried over from the earlier legislation, is also poor. The improvement in Argentina's macrofiscal indicators since the 2001 crisis is due to a set of convergent factors (new taxes, faster growth, inflation, restructuring of the public debt) and cannot be attributed to the passing of the 2004 FRL. As a proportion of GDP, the national primary fiscal result in 2005 was over 1\% lower than in the previous year and, as mentioned earlier, the rule that is most important for a period of expansion like

\footnotetext{
${ }^{36}$ In mid-March 2006, the executive amended the rules on minimum thresholds for profits tax liability without presenting any offsetting measure.
}

In summary, a preliminary assessment of compliance with the rules established in the FRL paints an unpromising picture that is reminiscent of the situation with its predecessor, law 25.152, in the early years of the decade. Despite the stark contrast in macroeconomic conditions at the time each came into force (extremely adverse for 25.152, favourable for the FRL), in neither case has the government (or public opinion generally) shown much interest in enforcing the rules established.

the one Argentina is currently experiencing was not followed: the limitation of spending growth. ${ }^{37}$

In contexts of institutional weakness like that in Argentina, where the executive amends laws with surprising frequency and ease, it is hard to imagine that a fiscal responsibility law might significantly constrain the decision-making of those in government, to the extent of correcting the pattern of behaviour in the public finances. ${ }^{38}$

As was mentioned in section II, some authors have argued that the great virtue of fiscal responsibility laws may simply be that they provide society with vehicles for building political consensus around the need to ensure the solvency of the public sector. In Latin America, the experience of Chile is revealing: the Chilean public sector was already meeting the structural fiscal surplus target of $1 \%$ of GDP several years before this was announced as a rule. ${ }^{39}$

\footnotetext{
${ }^{37}$ The primary result fell from $4.04 \%$ of GDP in 2004 to $2.98 \%$ in 2005 . The financial result fell from $2.6 \%$ to $0.68 \%$ in the same period.

38 Eifert, Gelb and Borje (2002) have studied the use of stabilization funds and other budgetary reforms in different countries with abundant oil resources, and have concluded that in countries deemed to be "factional democracies" (a category in which they include Argentina and other countries of the region) these schemes do not work properly unless they have strong political support.

${ }^{39}$ The Chilean rule has another striking characteristic which contrasts with the recommendations of the literature: it is not based on any legal or constitutional instrument whatsoever. See Marcel (2006) and Vial (2003).
} 
In Argentina, parliamentary debates on fiscal responsibility bills have not been associated with an in-depth public discussion of the importance of fiscal discipline. Despite the traumatic earlier experience, the FRL was debated for less than two months in Congress and no reflections and/or discussions on the issue were forthcoming from other sectors with close connections to the public finances.

Far from being treated as tools for regulating long-term fiscal policy, the rules have been used to respond to short-term needs, with an evident lack of concern about their subsequent performance. In 1999, the drafters of law 25.152 took to its limit the idea of the "fiscal rule as signal" (Drazen, 2002) in an effort to convey an unyielding commitment by the authorities to the convertibility regime.

In 2004, however, it seemed foolish to imagine that passing a new fiscal responsibility law could provide a positive signal about the fiscal commitment of the authorities. With public debt repayments suspended, the credibility of the Argentine Treasury had fallen very low and was unlikely to be improved by a new law from Congress offering yet another promise of fiscal discipline.

So why was the FRL passed? Despite having no potential whatsoever as a "signal", the law was useful for other goals being pursued at the time, chiefly that of ensuring the viability of the stand-by agreement then in force between Argentina and the IMF. The Fund was keeping up its recurrent pressure for the approval of structural reforms, especially in the fiscal area, but the Argentine authorities saw how unhelpful it would be to force along the debate on reform of the tax revenuesharing regime. Securing a fiscal responsibility law that was lauded in academic circles and by the multilateral agencies became an honourable way out for Argentina and the IMF negotiators. From the Argentine perspective, passing the new fiscal responsibility law would be a positive step if it gave greater viability to the programme with the IMF, while it would also serve to institutionalize the bilateral financial assistance programmes with the provinces the old ordered financing programmes.

Looking ahead, this analysis of events leads us to the paradoxical recommendation that Argentina should once again reopen the legislative debate on fiscal responsibility. The legislation now in force is so confused that the rules need to be consolidated and organized, probably in a single body of law. The aim should not be to produce a third fiscal rule in response to a temporary predicament or to the wishes of some multilateral organization, but to rationalize the existing legislation, stripping it of redundant provisions and of objectives that are unlikely to be attained.

This rationalization of the fiscal responsibility legislation could be an opportunity to generate a broad public debate on the advantages of fiscal discipline and budgetary good practice, involving all sectors of politics and society with an interest in the subject. Even if formally less ambitious, a review of the fiscal legislation that yielded a consensus on the subject in society would surely have far more beneficial effects on the performance of the public accounts.

Regionally, the Argentine experience should also provide a warning to the multilateral organizations, which are only too ready to include the approval of a fiscal rule among the conditions they lay down in their assistance programmes. In countries with low fiscal credibility and weak institutions, not only may rules prove completely ineffective in fiscal terms, but nonenforcement may further weaken the fragile institutional environment that undermined their effectiveness in the first place..$^{40}$ Perhaps it is the multilateral organizations that should follow a new rule: do not press for the approval of fiscal rules in countries that establish them only in order to obtain the financing these organizations can provide.

(Original: Spanish) ${ }^{40}$ Vial (2003) examines the problems that have arisen with the
implementation of IMF-sponsored laws creating fiscal rules in Peru
and Ecuador. 


\section{Bibliography}

Alesina, A. and R. Perotti (1996): Fiscal discipline and the budget process, American Economic Review, vol. 86, No. 2, Nashville, Tennessee, American Economic Association, May.

ASAP (Argentine Public Budget and Financial Administration Association) (2005): Informe de ejecución, IV trimestre del 2005, Buenos Aires.

Braun, M. and M. Tommasi (2004): Subnational fiscal rules: a game theoretic approach, in G. Kopits (ed.), Rules-Based Fiscal Policy in Emerging Markets: Background, Analysis and Prospects, Houndmills, Palgrave Macmillan.

Cetrángolo, O. and J.P. Jiménez (2004): Las relaciones entre niveles de gobierno en Argentina: raices históricas, instituciones y conflictos persistentes, Gestión pública series, No. 47, LC/L.2201-P, Santiago, Chile, Economic Commission for Latin America and the Caribbean (ECLAC). United Nations publication, Sales No. S.04.II.G.126.

Consejo Federal de Responsabilidad Fiscal (2006): Evaluación del cumplimiento: Régimen Federal de Responsabilidad Fiscal. Ejercicio 2005, Buenos Aires, June.

Cukierman, A. (1992): Central Bank Strategy, Credibility and Independence: Theory and Evidence, Cambridge, Massachusetts, The MIT Press.

Drazen, A. (2002): Political Economy in Macroeconomics, Princeton, Princeton University Press

Drazen, A. and A. Brender (2005): Political budget cycles in new versus established democracies, Journal of Monetary Economics, vol. 52, No. 7, Amsterdam, Elsevier, October.

Eifert, B., A. Gelb and N. Borje (2002): The Political Economy of Fiscal Policy and Economic Management in Oil Exporting Countries, Policy Research Working Paper, No. 2899, Washington, D.C., International Monetary Fund.

Gadano, N. (2003): Rompiendo las reglas: Argentina y la Ley de Responsabilidad Fiscal, Desarrollo económico, No. 170, Buenos Aires, Institute of Economic and Social Development (IDES), July-September

Homer (2003): Book XII, The Odyssey, London, Penguin Classics. IMF (International Monetary Fund) (2005): Argentina: 2005 Article IV Consultation: Staff Report, Imf Country Report, No. 05/236, Washington, D.C.

(2004a): Argentina: Second Review under the Stand-By Arrangement and Requests for Modification and Waiver of Performance Criteria: Staff Report, Imf Staff Country Reports, No. 195, Washington, D.C., July.

(2004b): Press Release, No. 04/16, Washington, D.C., 28 January.

(2003a): Press Release, No. 03/160, Washington, D.C., 20 September.

(2003b): Argentina: Request for Stand-By Arrangement and Request for Extension of Repurchase Expectations, Imf Staff Country Reports, No. 03/392, Washington, D.C., 19 December.
Kopits, G. (2001): Fiscal Rules: Useful Policy Framework or Unnecessary Ornament?, Imf Working Paper, No. 01/145, Washington, D.C., International Monetary Fund, October.

Kopits, G. and S. Symansky (1998): Fiscal Policy Rules, Imf Occasional Paper, No. 162, Washington, D.C., International Monetary Fund.

Kydland, F. and E. Prescott (1977): Rules rather than discretion: the inconsistency of optimal plans, The Journal of Political Economy, vol. 85, No. 3, Chicago, The University of Chicago Press, June.

Lavagna, R. (2004): Hay 13 programas de financiamiento vigentes, La Nación, Buenos Aires, 15 June.

Makón, M. (1997): La reforma del sistema presupuestario nacional, Revista ASAP, No. 29, Buenos Aires, Argentine Public Budget and Financial Administration Association, April.

Marcel, M. (2006): Cinco años de balance estructural en Chile: una evaluación, presentation at the Regional Seminar on Fiscal Policy (Santiago, Chile, 23-26 January).

Marx, K. (1963): The Eighteenth Brumaire of Louis Bonaparte, New York, International Publishers.

Milesi-Ferretti, G. (2000): Good, Bad or Ugly? On the Effects of Fiscal Rules with Creative Accounting, Imf Working Paper, No. 172, Washington, D.C., International Monetary Fund.

Persson, T. and G. Tabellini (2000), Political Economics: Explaining Economic Policy, Cambridge, Massachusetts, The MIT Press.

Schick, A. (2002): Budget Rules versus Political Will, document prepared for the Imf/World Bank Conference on Rules-Based Fiscal Policy in Emerging Market Economies (Oaxaca, Mexico, 14-16 February).

Tabellini, G. and A. Alesina (1988): Voting on the Budget Deficit, UCLA Working Paper, No. 539, Los Angeles, California, University of California, December.

Ter-Minassian, T. (2006): Enhancing Fiscal Discipline Over the Cycle, document presented at the Regional Seminar on Fiscal Policy (Santiago, Chile, January 2006).

Tommasi, M. (1998): Instituciones y resultados fiscales, Desarrollo económico, vol. 38, No. 149, Buenos Aires, Institute of Economic and Social Development (IDES).

Velasco, A. (1999): A model of endogenous fiscal deficits and delayed fiscal reforms, in J. Poterba and J. von Hagen (eds.), Fiscal Institutions and Fiscal Performance, NBER Working Paper, No. 6336, Cambridge, Massachusetts, National Bureau of Economic Research.

Vial, J. (2003): Politica fiscal en un contexto de elevada volatilidad externa, Caracas, Andean Development Corporation (ADC).

Weingast, B.R., K.A. Shepsle and C. Johnsen (1981): The political economy of benefits and costs: a neoclassical approach to distributive politics, The Journal of Political Economy, vol. 89, No. 4, Chicago, University of Chicago Press. 